
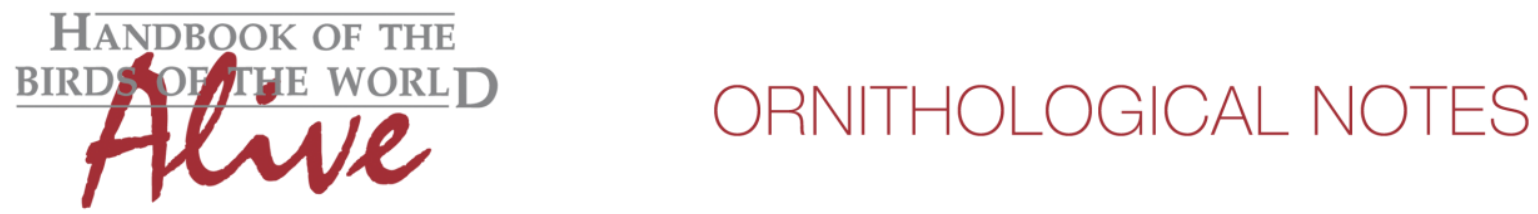

\title{
Notes on the vocalizations of Ethiopian Bee-eater (Merops lafresnayii) and Blue-breasted Bee-eater (Merops variegatus)
}

Peter Boesman

In the following text, I briefly analyze and compare the voices of Ethiopian Bee-eater (Merops lafresnayii) and Blue-breasted Bee-eater (Merops variegatus). I also try to quantify the extent of any vocal differences using the criteria proposed by Tobias et al. (2010), as a basis for taxonomic review. I have made use of sound recordings available online at Xeno Canto $(\mathrm{XC})$ and the Macaulay Library (ML).

M. lafresnayii was only recently elevated to species rank (del Hoyo \& Collar 2014), mainly based on differences in plumage and biometrics. Other taxonomic lists seemingly have not followed such treatment to date.

The voice of both species has never been compared in depth, and hardly any recordings were available to do so. I have recently been able to make sound recordings of both species, in particular the song-like vocalization heard when two birds (presumably a pair) meet. The available recordings suggest that there are indeed two distinct vocal groups.

\section{Iafresnayii}

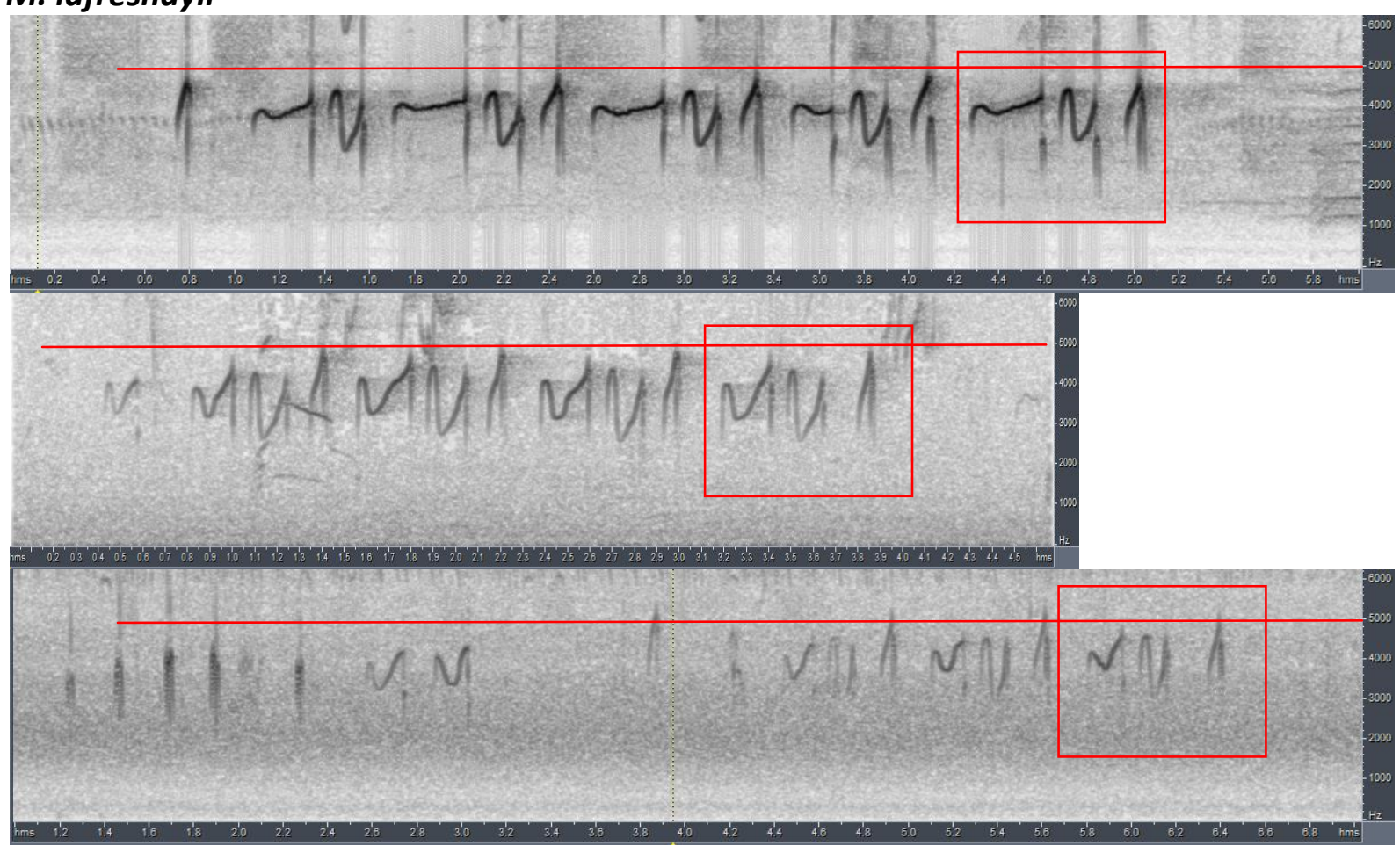

From top to bottom: XC300472 Lake Langano, Ethiopia, Peter Boesman; XC41547 Addis Ababa, Ethiopia, Rory Nefdt; XC300464 Gibe gorge, Ethiopia, Peter Boesman. 


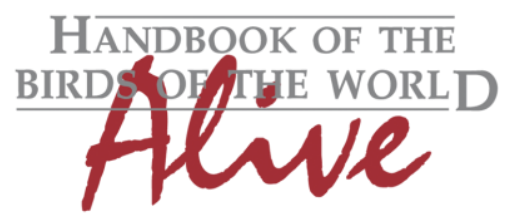

\section{ORNITHOLOGICAL NOTES}

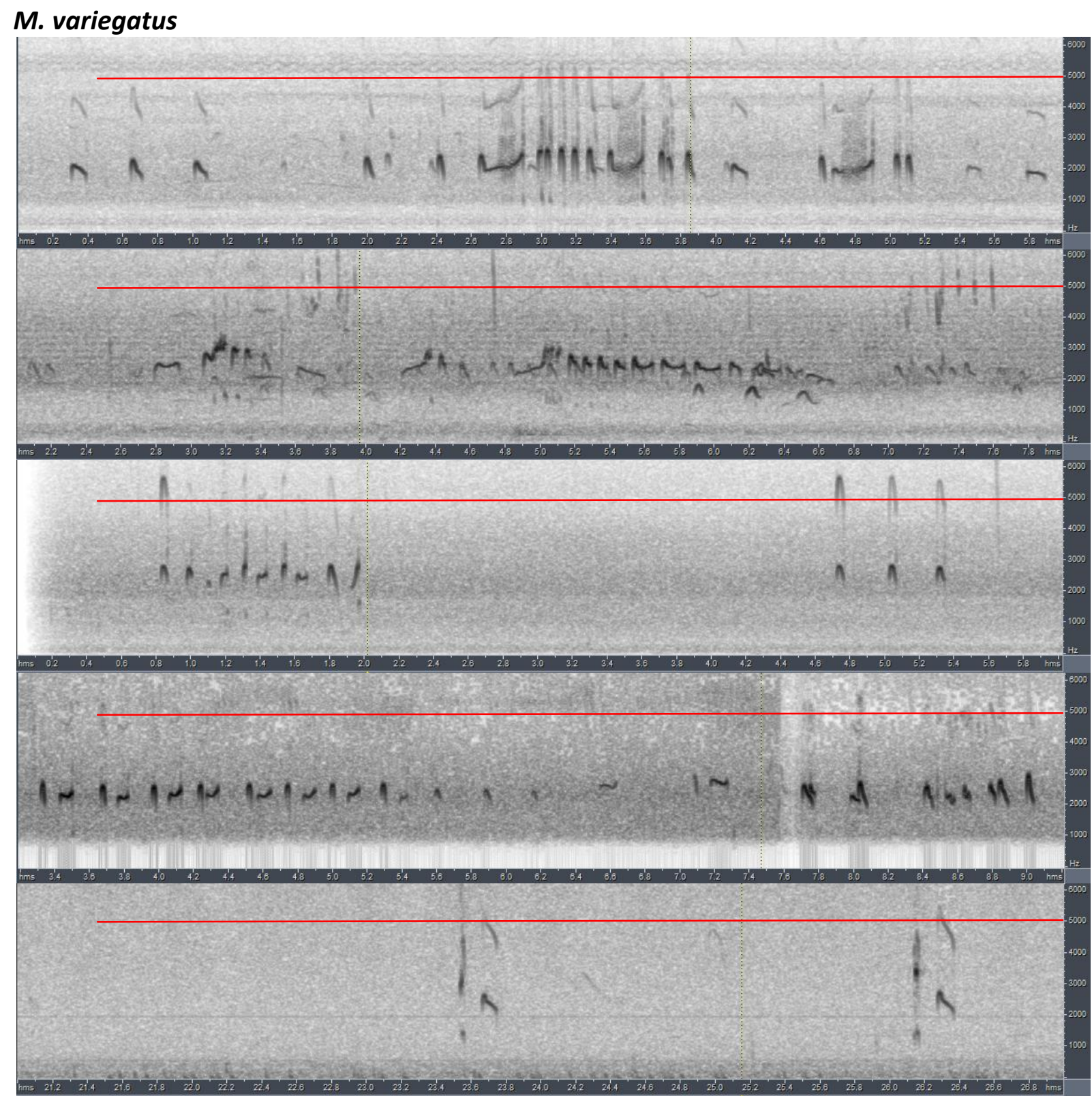

From top to bottom: XC339289 Kawambwa, Luapula, Zambia, Peter Boesman; XC339287 Kawambwa, Luapula, Zambia, Peter Boesman; XC339284 Kasama, Northern province, Zambia, Peter Boesman; Zambia, Bob Stjernstedt, ML1318, DR Congo, Peter Kaestner.

Song or greeting call of $M$. lafresnayii is a rhythmic phrase with a repeated three-note pattern. All notes reach a maximum base frequency of $4-5 \mathrm{kHz}$, and thus sound lively and piping to the ear. In M. variegatus, greeting call combines short 'pip' notes with slightly longer whistles, which occasionally sound burry. All notes reach a maximum base frequency of only $2.5-3 \mathrm{kHz}$, and they sound quite mellow and subdued, somewhat like a small Charadrius plover.

The difference in voice of both species is striking. Besides the entirely different frequency range (!), there is also the stereotyped, repeated rhythmic three-note pattern of $M$. lafresnayii vs. the rather loose series of calls in M. variegatus. 

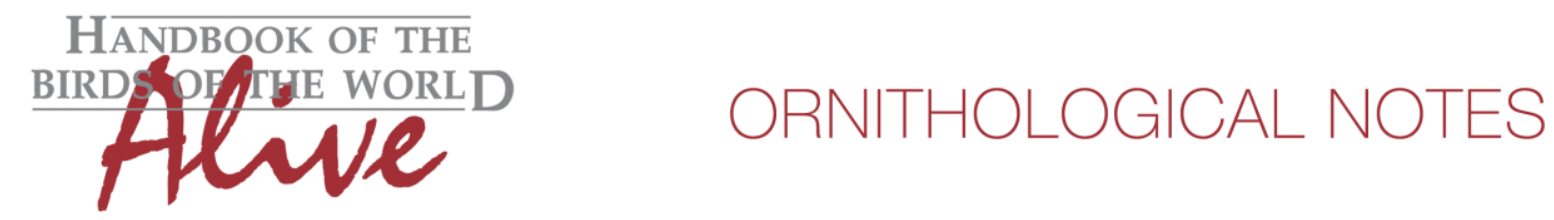

When applying the Tobias criteria, this would lead to scores for vocal difference of 3-4 for maximum frequency and 2-3 for duration of repeated patterns, for a total vocal score of about $6(!)$.

del Hoyo and Collar furthermore indicated that M. lafresnayii is actually more closely related to $M$. oreobates. I therefore also discuss the voice of that species.

\section{M. oreobates}

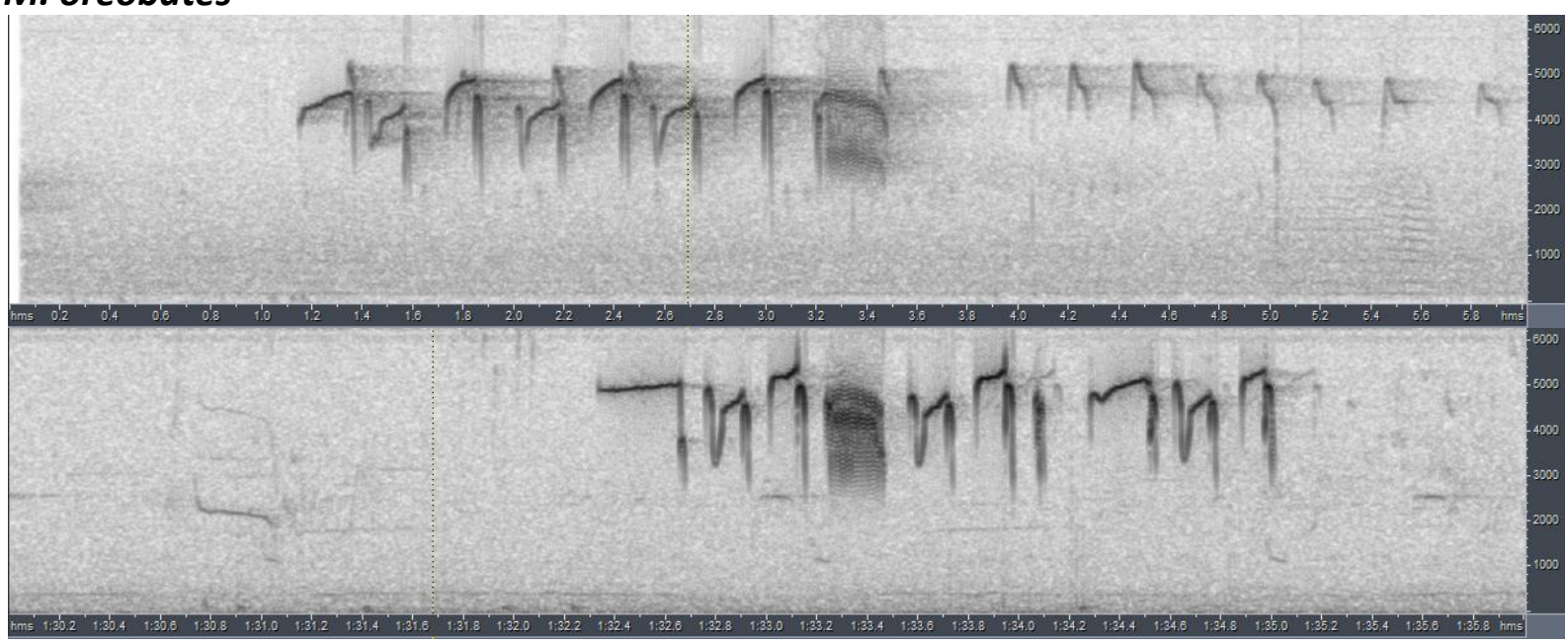

From top to bottom: XC364368 Kakamega Forest, Kenya, James Bradley; ML26308 Impenetrable Forest, Uganda, Keith Stuart.

It would seem that $M$. oreobates indeed shares with $M$. lafresnayii a rather rhythmic phrase with notes reaching c. $5 \mathrm{kHz}$. Note shapes are, however, clearly different, and $M$. oreobates seems to include very burry notes in its song phrase.

I thus conclude that analysis of voice concurs fully with the taxonomic treatment in del Hoyo \& Collar (2014), with major differences between M. lafresnayii and M. variegatus, the former being actually closer vocally to $M$. oreobates.

These conclusions should also be checked for West African populations of M. variegatus when sound recordings become available.

This note was finalized on 9th May 2017, using sound recordings available online at that time. I thank, in particular, the many sound recordists who made their recordings of this species available on XC and ML, and Guy Kirwan for revising the original text.

\section{References}

del Hoyo, J. \& Collar, N.J. (2014) HBW and Birdlife International Illustrated Checklist of the Birds of the World. Vol. 1. Non-passerines. Lynx Edicions. Barcelona.

Tobias, J.A., Seddon, N., Spottiswoode, C.N., Pilgrim, J.D., Fishpool, L.D.C. \& Collar, N.J. (2010) Quantitative criteria for species delimitation. Ibis 152(4): 724-746. 


\section{Recommended citation}

Peter Boesman (2017) Notes on the vocalizations of Ethiopian Bee-eater (Merops lafresnayii) and Blue-breasted Bee-eater (Merops variegatus). HBW Alive Ornithological Note. In: Handbook of the Birds of the World Alive. Lynx Edicions, Barcelona. (retrieved from http://www.hbw.com/node/1374814 on 9 May 2017). 